\section{A priliminary report on the ichthyofauna of Yedayanthittu Estuary (Tamil Nadu, India) and rivulets draining into it}

\author{
M. Eric Ramanujam ${ }^{1}$ \& R. Anbarasan ${ }^{2}$ \\ 1,2 Pitchandikulam Bioresource Centre, Auroville, Puducherry \\ 605101, India \\ Email: ${ }^{1}$ tdef@auroville.org.in; ericramanujam@yahoo.co.in; \\ 2 anbarasan_ecol@yahoo.com
}

Yedayanthittu Estuary is part of the Kaliveli wetland complex which includes the Kaliveli Floodplain, Uppukalli Creek and lowland streams draining into it. The ichthyofauna of Kaliveli Floodplain and Uppukalli Creek has already been assessed (Ramanujam 2005). This report concerns the list of species found in the estuary and and lowland streams.

\section{Study Area and Methods}

The Kaliveli complex has already been described (Ramanujam 2005). Lowland drains behind Kurumpuram Reserve Forest (Villupuram District, Tamil Nadu) are part of the Arni River complex and has its origin in the Eastern Ghats.

Yedayanthittu or Muttukadu Estuary $\left(12^{\circ} 12^{\prime}-12^{\circ} 15^{\prime} \mathrm{N} \&\right.$ $70^{\circ} 56^{\prime}-80^{\circ} 0^{\prime} \mathrm{E}$ ) extends from a little north of Marakkanam Road Bridge to the point of confluence with the Bay of Bengal at Alamparai (Kancheepuram District, Tamil Nadu). It is an area of intertidal mudflats and salt pans. It was once linked to Pulicat Lake via Chennai by the Buckingham Canal (Scott 1998). The feature of the estuary is that during the monsoon season (September-mid November) the salinity is low $(<1600 u \mathrm{~S} / \mathrm{cm})$, but during the rest of the year it is brackish $(1,600-4,800 \mathrm{uS} / \mathrm{cm})$, saline $(4,800-51,500 \mathrm{uS} / \mathrm{cm})$ and even hypersaline $(>51,500 \mathrm{uS} / \mathrm{cm})$ depending on the tides and proximity to the sea. The naturally occurring vegetation consists of sea grasses such as Halophila ovalis, mangroves such as Avicennia marina and Rhizophora sp. (the latter has been planted lately) and algae such as Chaetomorpha, Enteromorpha, etc. A degraded mangrove swamp also exists whose dominant

Date of online publication 26 May 2009

ISSN 0974-7907 (online) | 0974-7893 (print)

Editor: M. Arunachalam

\section{Manuscript details:}

Ms \# 01701

Received 05 January 2007

Final received 21 January 2008

Finally accepted 15 May 2009

Citation: Ramanujam, M.E. \& R. Anbarasan (2008). A priliminary report on the ichthyofauna of Yedayanthittu Estuary (Tamil Nadu, India) and rivulets draining into it. Journal of Threatened Taxa 1(5): 287-294.

Copyright: (c) M. Eric Ramanujam \& R. Anbarasan 2009. Creative Commons Attribution 3.0 Unported License. JoTT allows unrestricted use of this article in any medium for non-profit purposes, reproduction and distribution by providing adequate credit to the authors and the source of publication.

Acknowledgements: We are thankful to UBS for the materials and means to carry out this study. We are also thankful to Dr. Rema Devi and Dr. T.J. Indra of Zoological Survey of India, Southern Regional Station for their invaluable help in identification of species.

\section{OPEN ACCESS |FREE DOWNLOAD (c) (1) (ே)}

vegetation includes Avicennia marina, Salicornia brachiata, Arthrocnemum indicum,

Suaeda maritima and Sesuvium portulacastrum.

The study period was from January 2006 to December 2006. Specimens were collected randomly with local fishermen all over the estuary. In addition, small fish stranded in pools when the water receeds (that commercialists ignore) were collected. Identification was based on Daniels (2002), Day (1878), Jayaram (1981), Talwar \& Kacker (1984), Talwar \& Jhingran (1991) and Venkateswarlu \& Rao (1986).

\section{Results and Discussion}

A total of 75 species were recorded under 14 orders and 37 families. Perciformes dominated with 32 species (42.66\%). 47 species were found exclusively in the estuary, 18 were in lowland streams and 10 species occurred both in the estuary and freshwater. Oreochromis mossambica is the only exotic species.

Inventorisation of living resources is of paramount importance to evolve conservation and management strategies, especially when economically important species are involved. As of date it is unfortunate that the Kaliveli Wetland has received little attention (from the viewpoint of the ichthyologist), this report gains importance as the Kaliveli Wetland has been described as one of the two most important wetlands along the Coromandel Coast of southern India (Perennou 1987; Perennou \& Santharam 1990).

\section{References}

Chacko, P.I., J.G. Abraham \& R. Andal (1953). Report of the survey of the flora, fauna and fisheries of the Pulicat Lake, Madras state, India. 1951-1952. Contribution of the Freshwater Fisheries Biological Station 8: 20

Cuvier, G. \& A. Valencienennes (1828-1849). Historie naturelle des poisons. Paris - Strasbourg, 11030pp + 621 pls.

Daniels, R.J.R. (2002). Freshwater Fishes of Peninsular India. Universities Press (India) Private Limited, Hyderabad, 288pp + 32pls

Day, F. (1878). The Fishes of India; Being a Aatural History of the Fishes Known to Inhabit the Seas and Freshwaters of India, Burma and Ceylon. Text and Atlas in four parts. William Dawson \& Sons Ltds., London, $\mathrm{xx}+778 \mathrm{pp}, 196 \mathrm{pls}$.

Devi, K.R., T.J. Indra \& M.B. Raghunathan (2004). Fishes of Pulicat Lake. Records of the Zoological Survey of India, 102: 33-42.

Jayram, K.C. (1981). The Freshwater Fishes of India, Pakistan, Bangladesh, Myanmar and Sri Lanka. Zoological Survey of India, Calcutta, 475pp.

Kaliyamurthy, M. \& K.J. Rao (1972). Preliminary observations on the food and feeding habits of some fishes of the Pulicat Lake. Journal of the Inland Fisheries Society of India IV: 115-121

Kaliyamurthy, M., S.K. Singh \& S.B. Singh (1986). Distribution of Gerres lucidus Cuv. In the Pulicat Lake. Matsya 12: 45-51.

Krishnan, S. \& S.S. Mishra (2004). An inventory of fish species described originally from fresh and coastal waters of Pondicherry. Records of the Zoological Survey of India 102: 65-87.

Perennou, C. (1987). Two important wetlands near Pondicherry. Blackbuck 3: 1-9.

Perennou, C. \& V. Santharam (1990). An anthropological survey of some wetlands in south-east India. Journal of the Bombay Natural History Society 87: 354-363.

Raman, K., M. Kaliyamurthy \& G.R.M. Rao (1975a). Studies on the biology of Ambassis gymnocephalus (Lac.) from Pulicate and Vembanad Lake. Matsya 1: 49-52.

Raman, K., K.V. Ramakrishna, K.V. Radhakrishnan \& G.R.M. Rao (1975b). On the hydrobiology and benthic ecology of Pulicat Lake. $3^{\text {rd }}$ All India Symposium on Estuarine Biology, Cochin.

Ramanujam, M.E. (2005). A preliminary report on the Ichthyofauna 
Table 1. Species diversity and occurrence of fish at Yedayanthittu Estuary and Rivulet behind Kurumpuram Reserve Forest

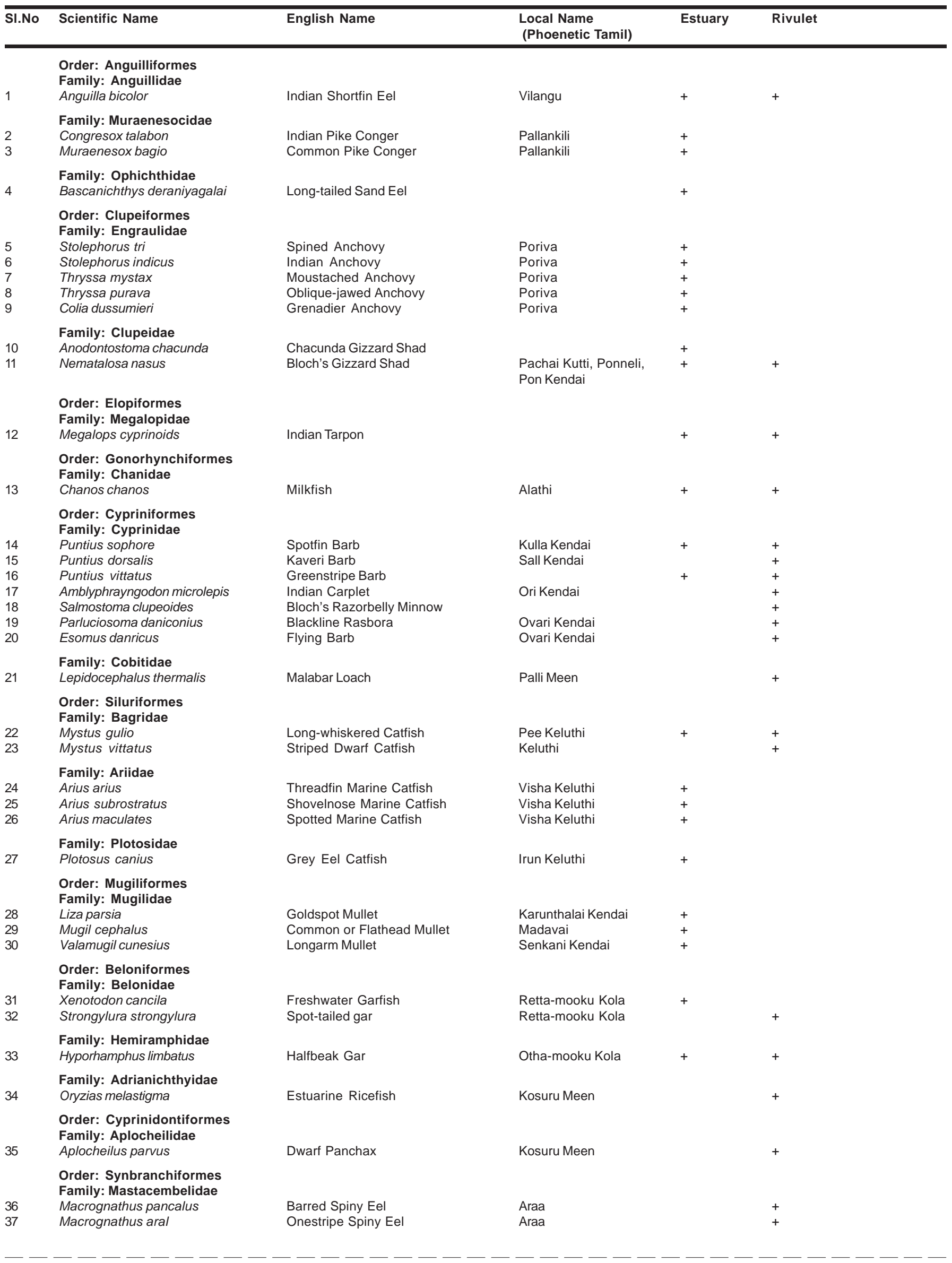




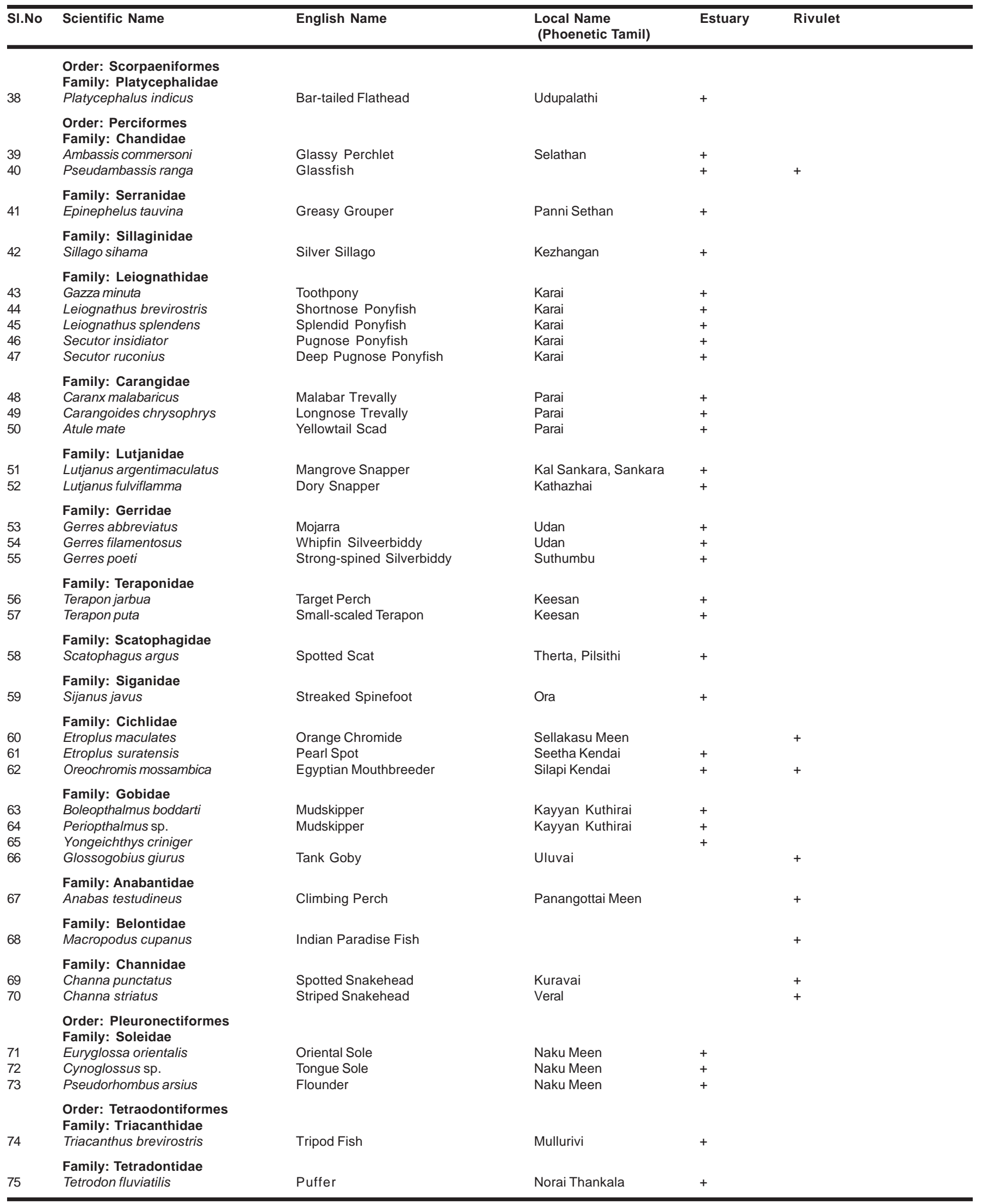




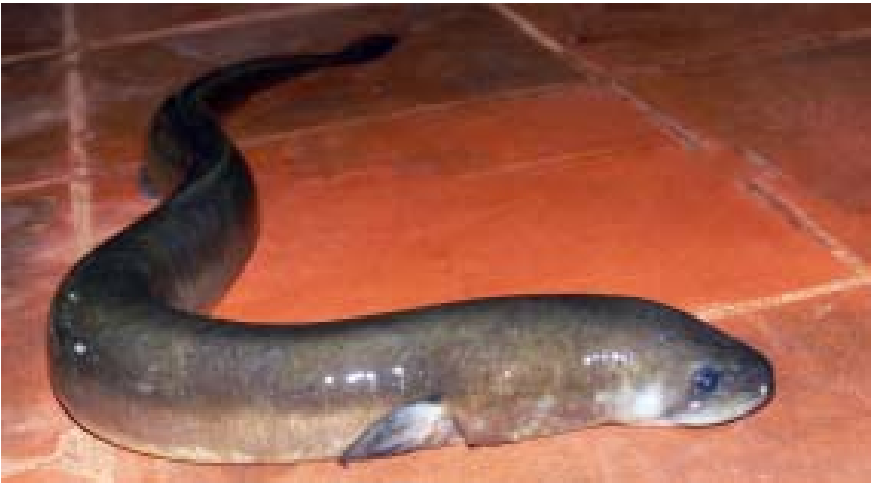

Image 1. Indian Shortfin Eel Anguilla bicolor

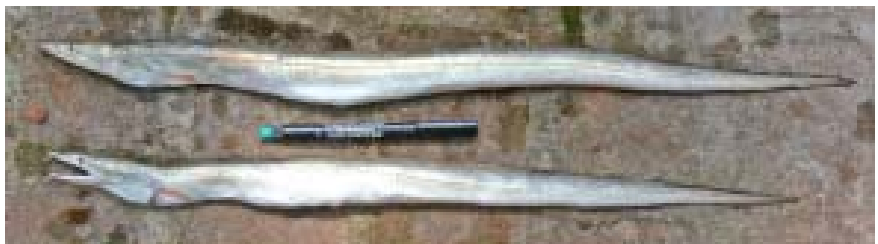

Image 2. Indian Pike conger Congresox talabon

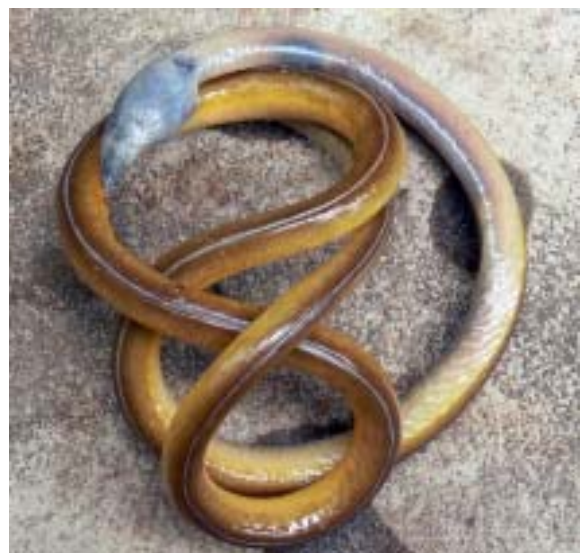

Image 3. Indian Longtailed Sand Eel Bascanchthys deraniyagalai

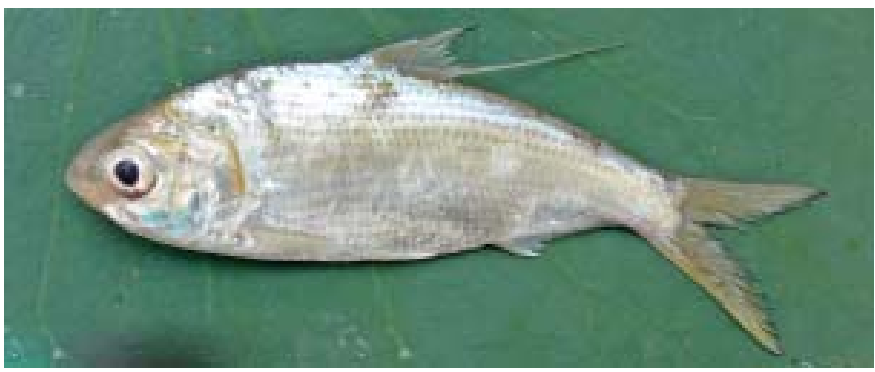

Image 4. Bloch's Gizzard Shad Nematalosa nasus

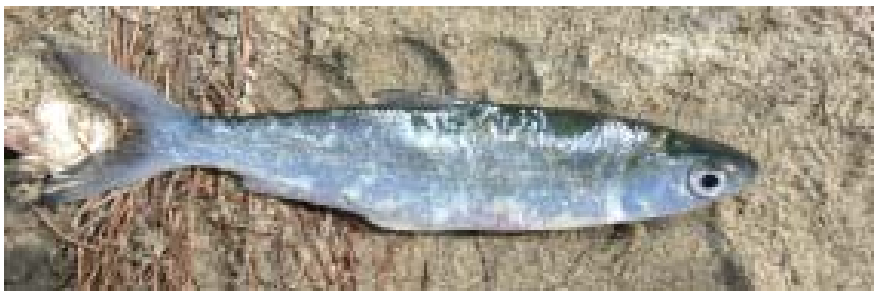

Image 5. Milkfish Chanos chanos

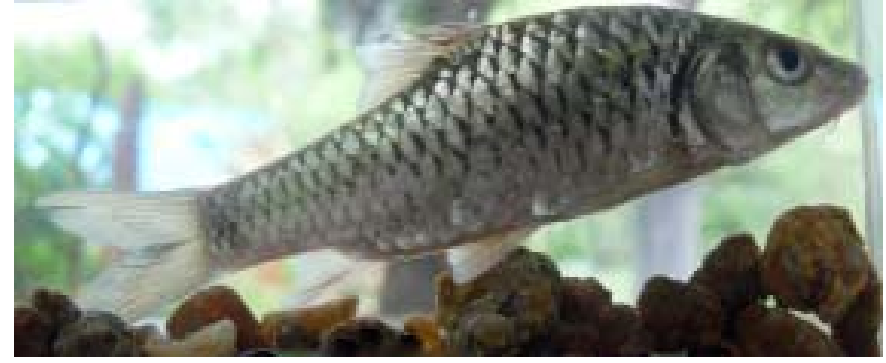

Image 6. Kaveri Barb Puntius dorsalis

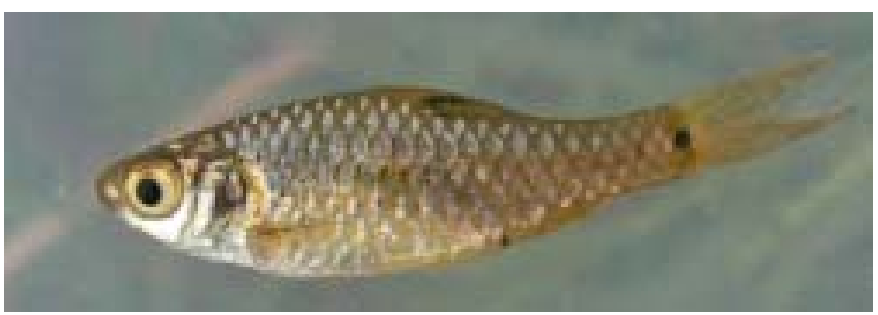

Image 7. Greenstripe Barb Puntius vittatus

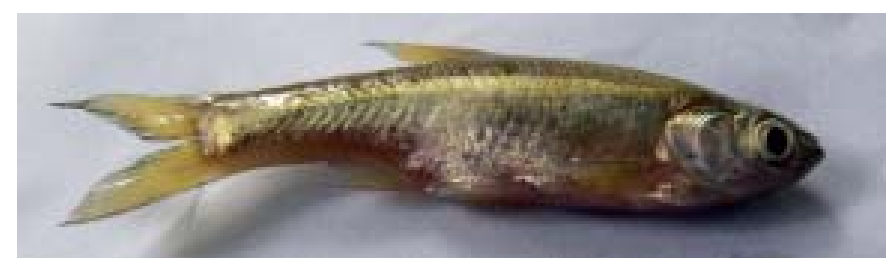

Image 8. Indian Carplet Amblypharyngodon microlepis

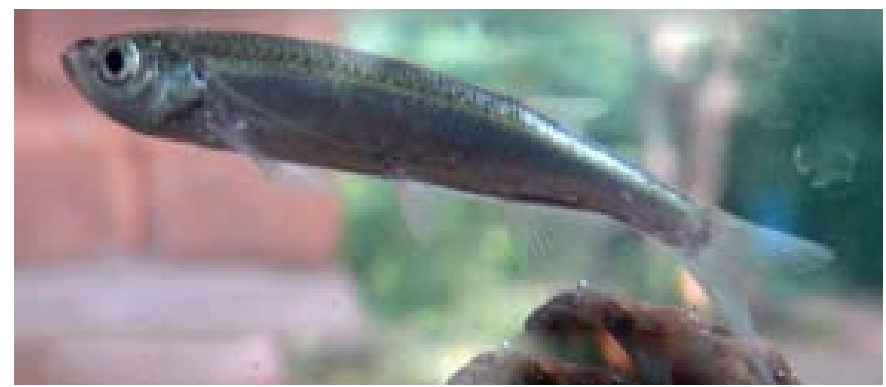

Image 9. Bloch's Razorbelly Minnow Salmostoma clupeoides

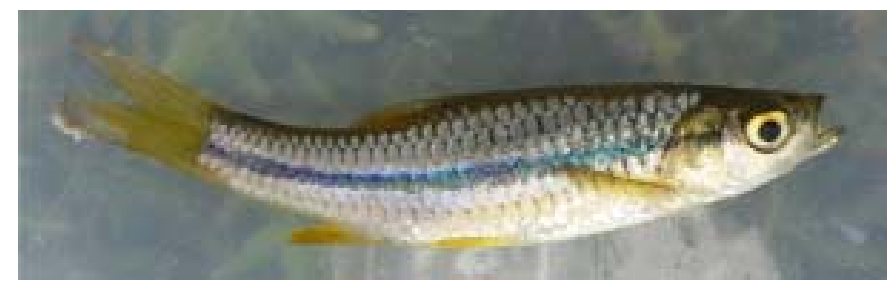

Image 10. Blackline Rasbora Parluciosoma daniconius

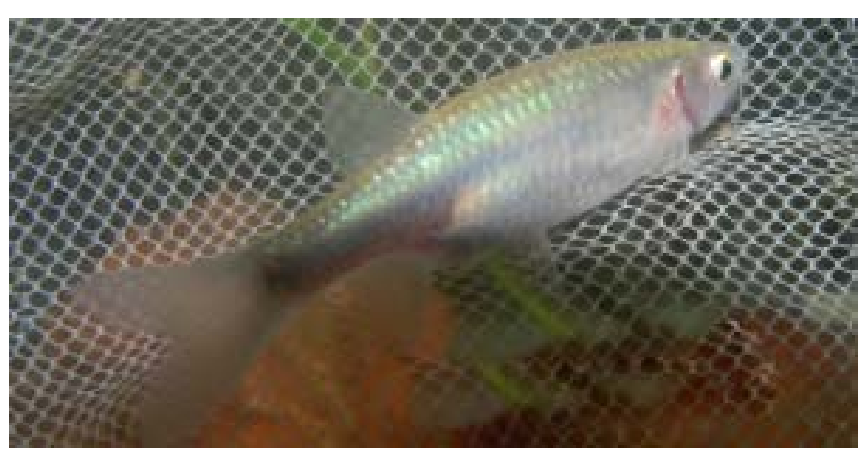

Image 11. Flying Barb Esomus thermoicos 


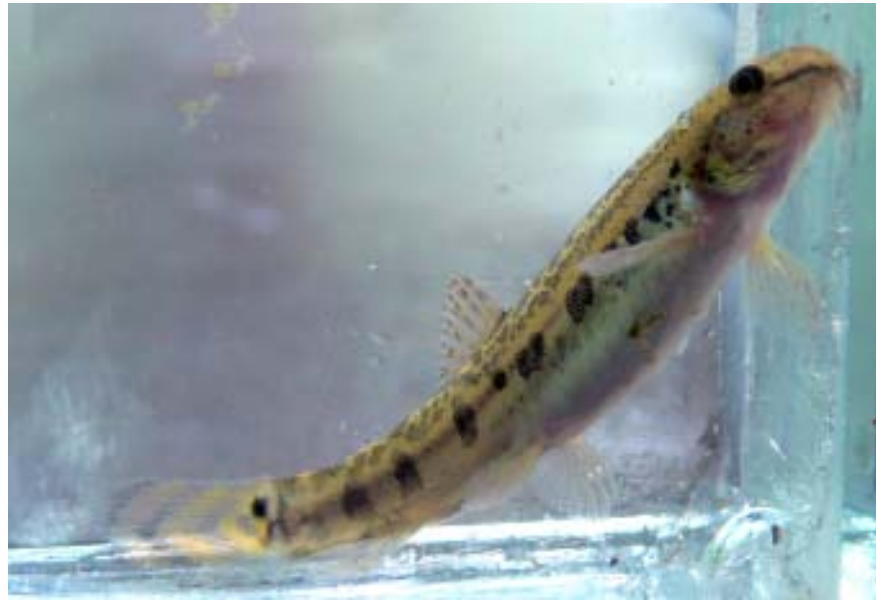

Image 12. Malabar Loach Lepidocephalus thermalis

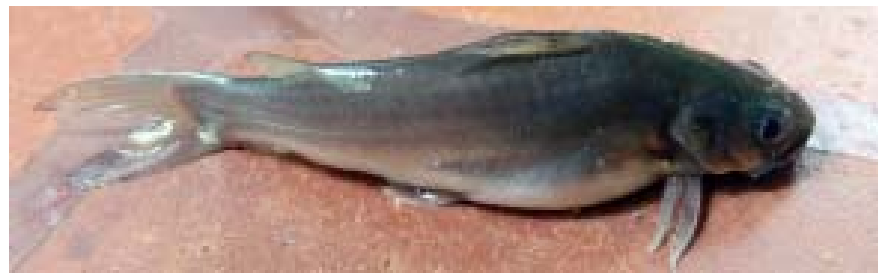

Image 13. Long-whiskered Catfish Mystus gulio

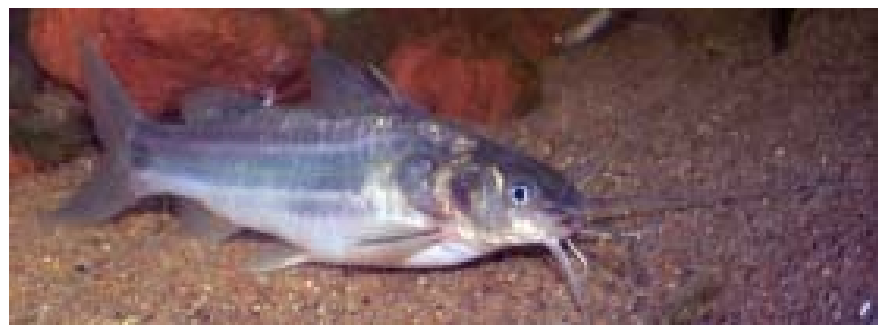

Image 14. Striped Dwarf Catfish Mystus vittatus

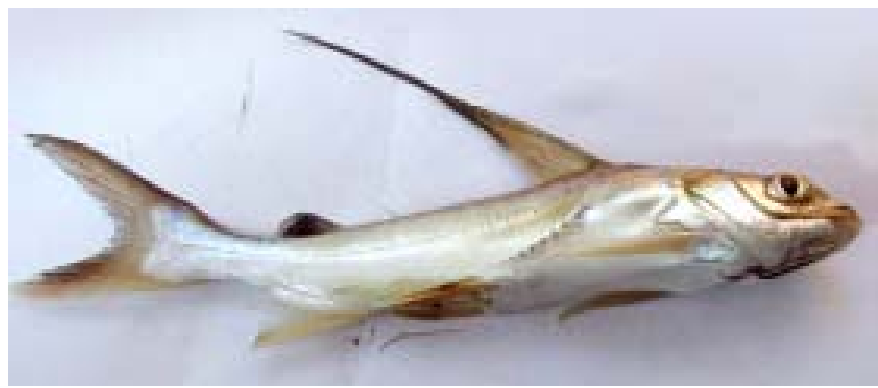

Image 15. Shovelnose Marine Catfish Arius subrostratus

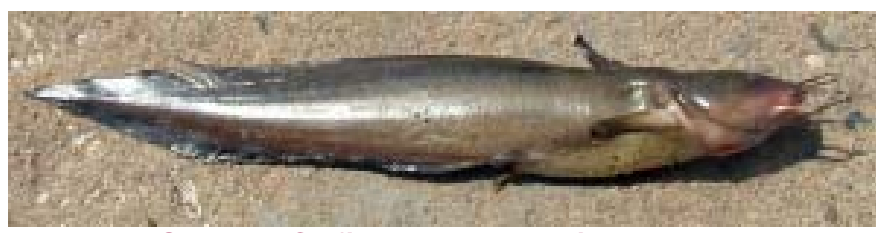

Image 16. Gray Eel Catfish Plotosus canius

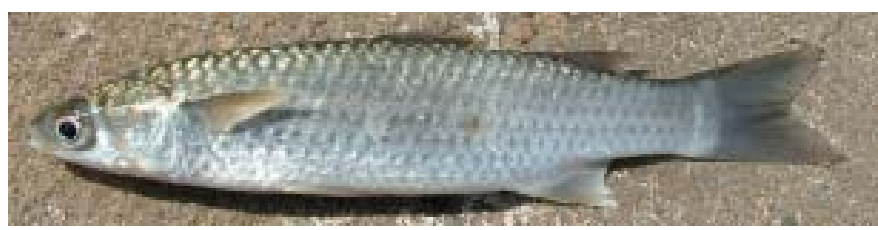

Image 17. Common or Flathead Mullet Mugil cephalus

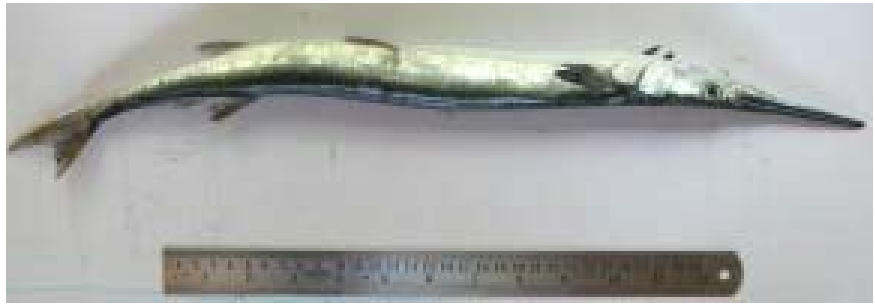

Image 18. Freshwater Garfish Xenentodon cancila

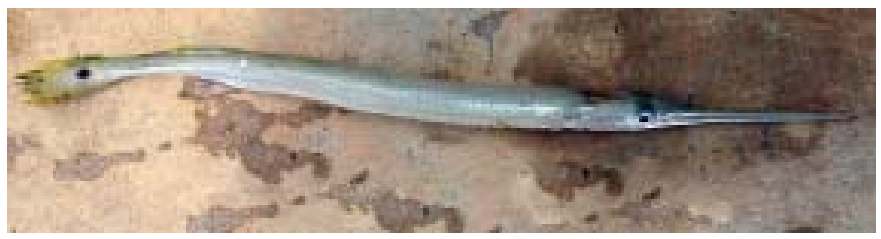

Image 19. Spot-tailed Gar Strongylura strongylura

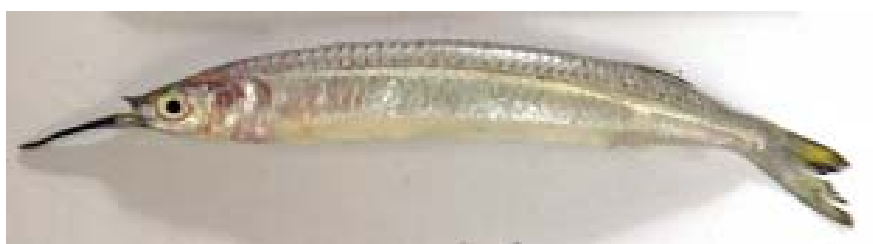

Image 20. Halfbeak Gar or Congaturi Halfbeak Hyporhamphus limbatus

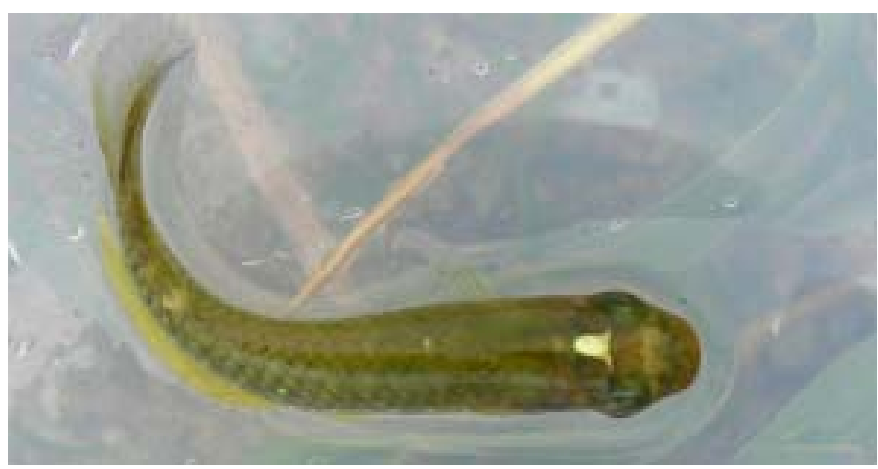

Image 21. Dwarf Panchax Aplocheilus parvus

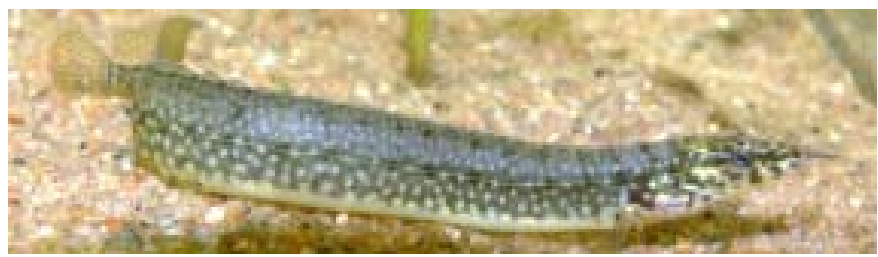

Image 22. Barred Spiny Eel Macrognathus pancalus

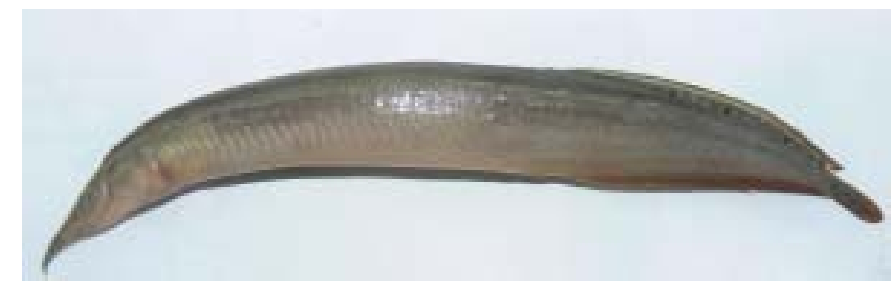

Image 23. Onestripe Spiny Eel Macrognathus aral 


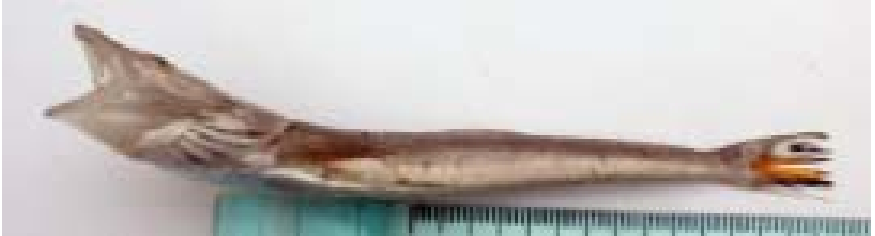
Image 24. Bar-tailed Flathead Platycephalus indicus

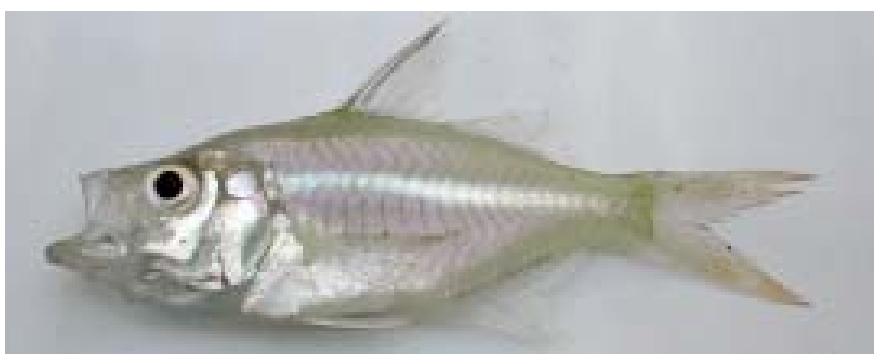

Image 25. Glassy Perchlet Ambassis commersoni

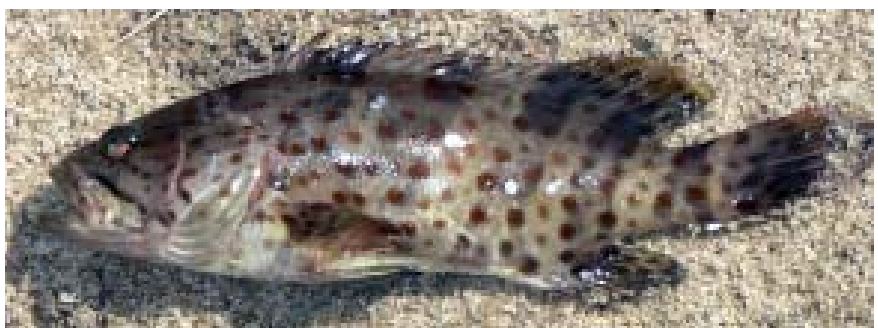
Image 26. Greasy Grouper Epinephelus tauvina

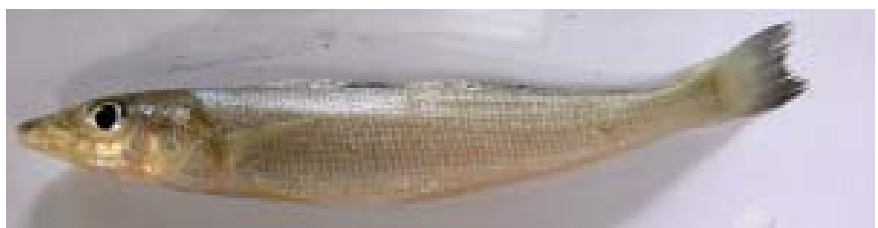

Image 27. Silver Sillago Sillago sihama

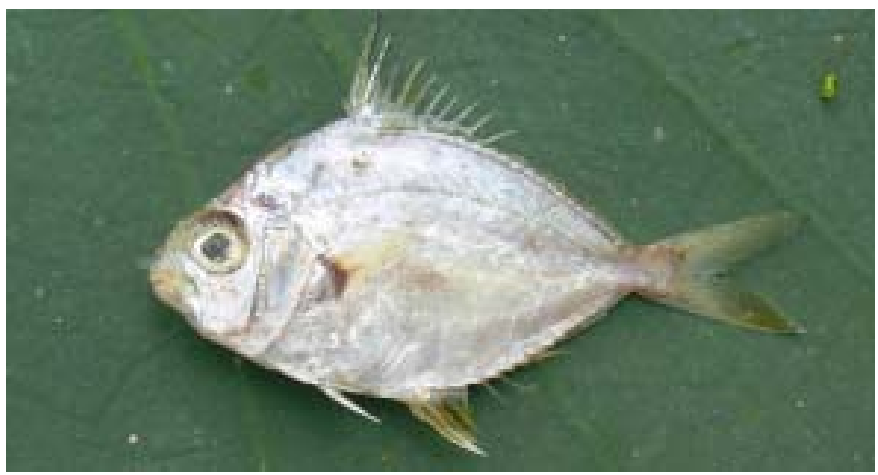

Image 28. Splendid Ponyfish Leiognathus splendens

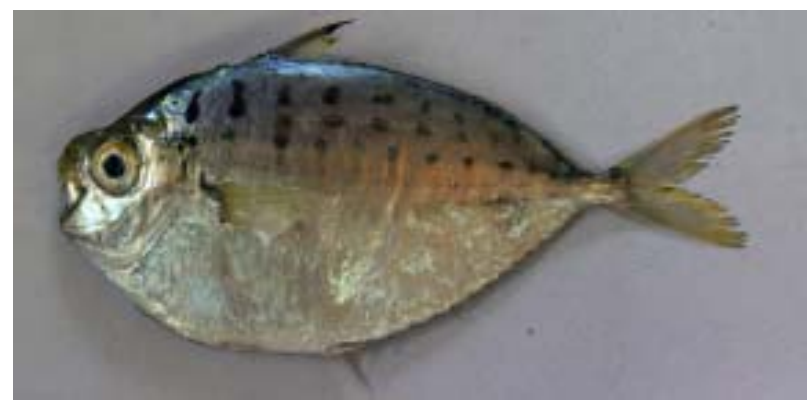

Image 29. Deep Pugnose Ponyfish Secutor ruconius

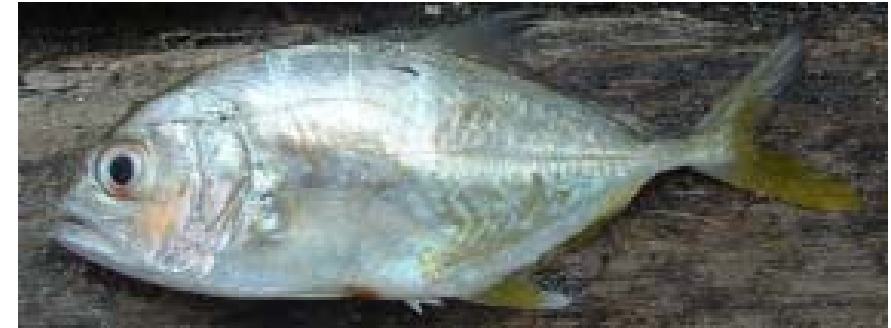

Image 30. Malabar Trevally Caranx malabaricus

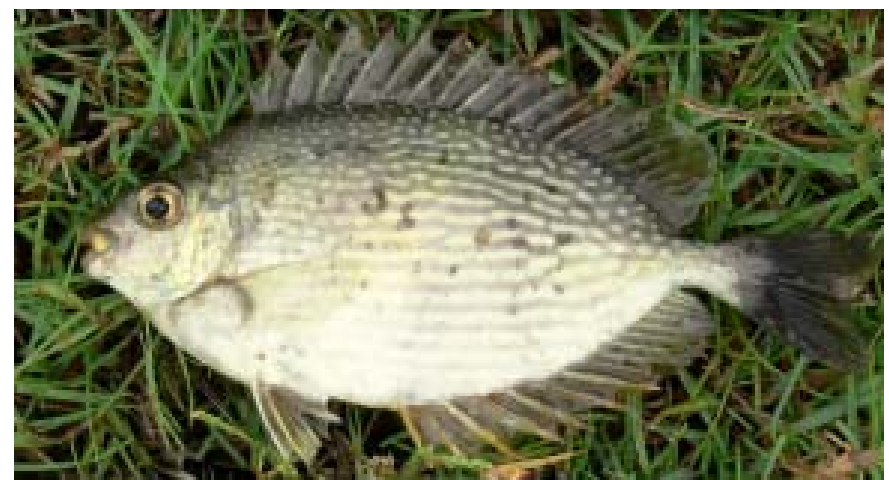

Image 31. Streaked Spinefoot Siganus javus

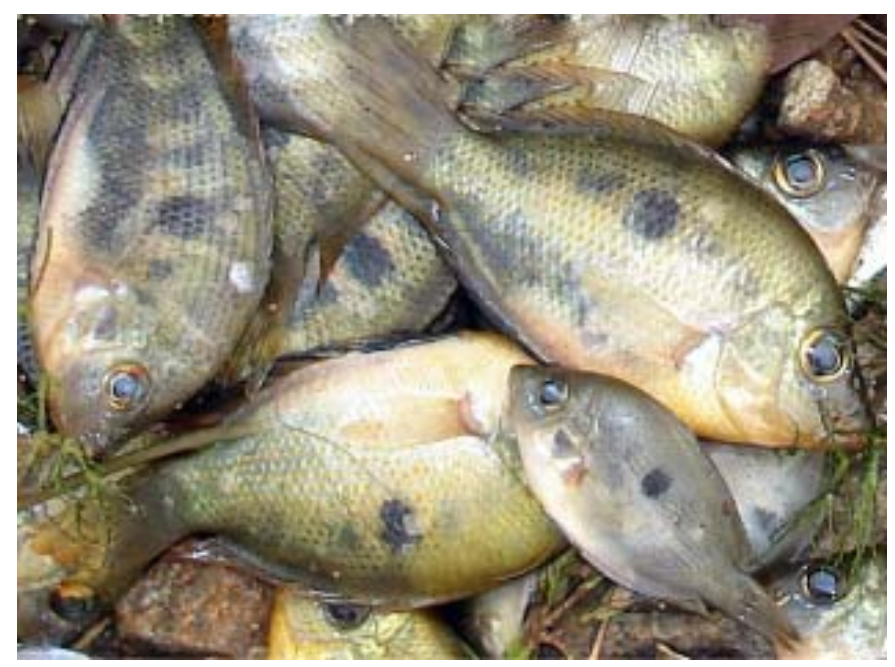

Image 32. Spotted Etroplus Etroplus maculatus

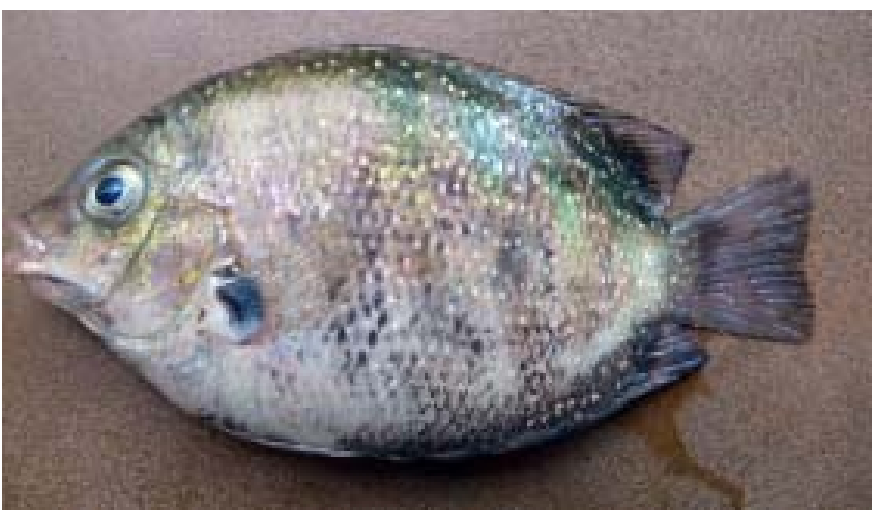

Image 33. Pearl Spot Etroplus suratensis 


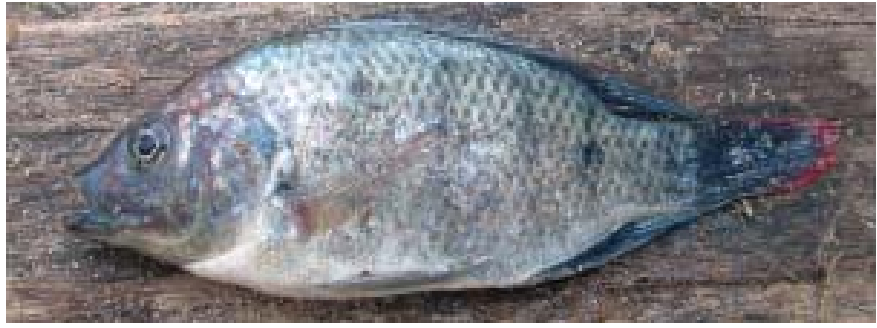

Image 34. Egyptian Mouthbrooder Oreochromis mossambica

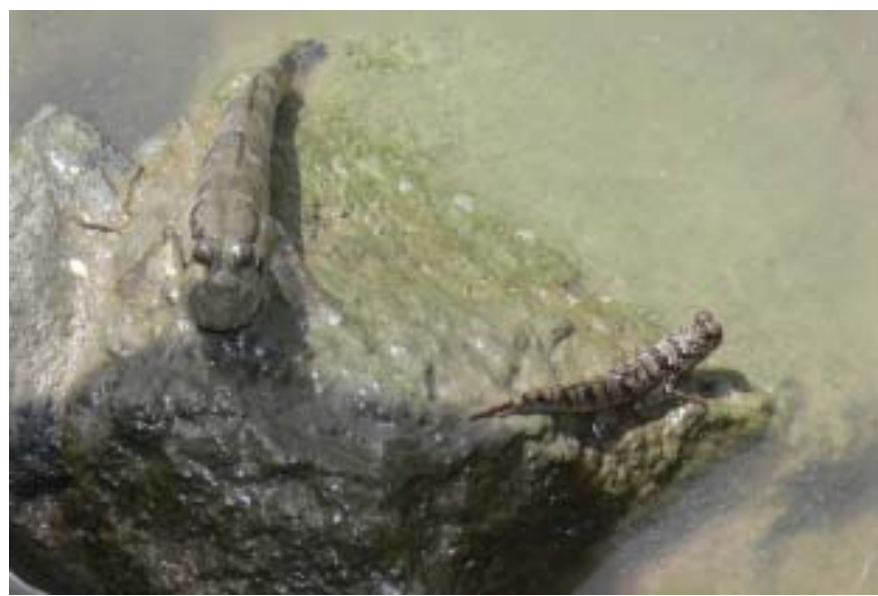

Images 35 \& 36 . Mudskipper Boleopthalmus boddarti \& Periophthalmus sp.

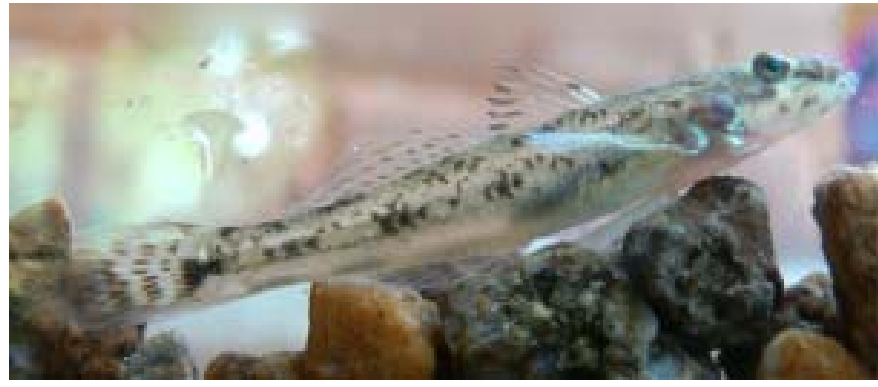

Images 37. Tank Goby Glossogobius giurus

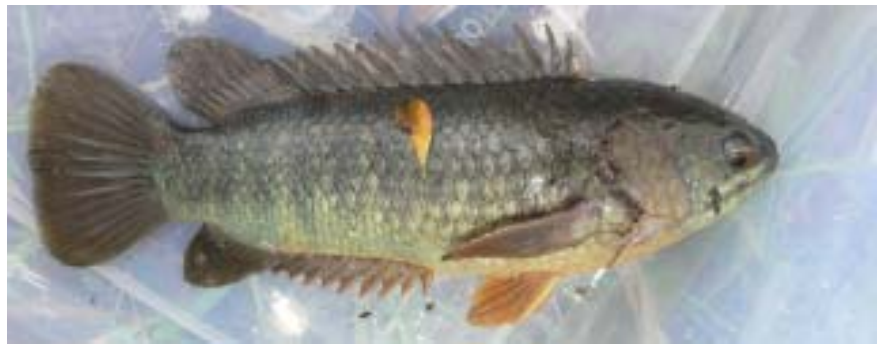

Image 38. Climbing Perch Anabas testudineus

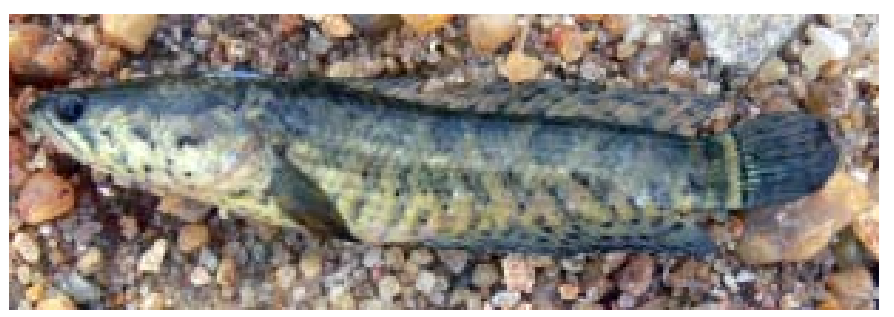

Image 39. Spotted Snakehead Channa punctatus

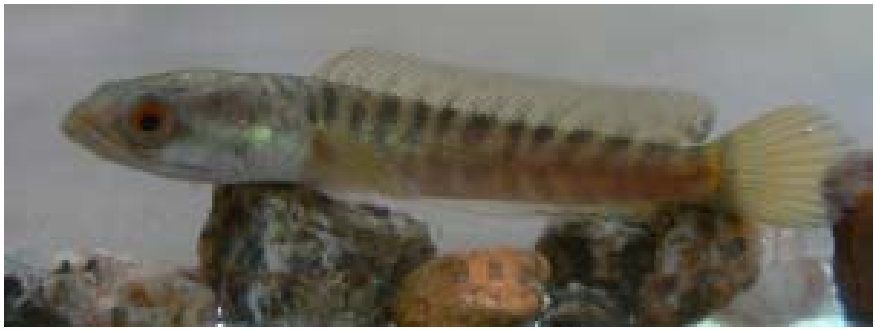

Image 40. Striped Snakehead Channa striatus

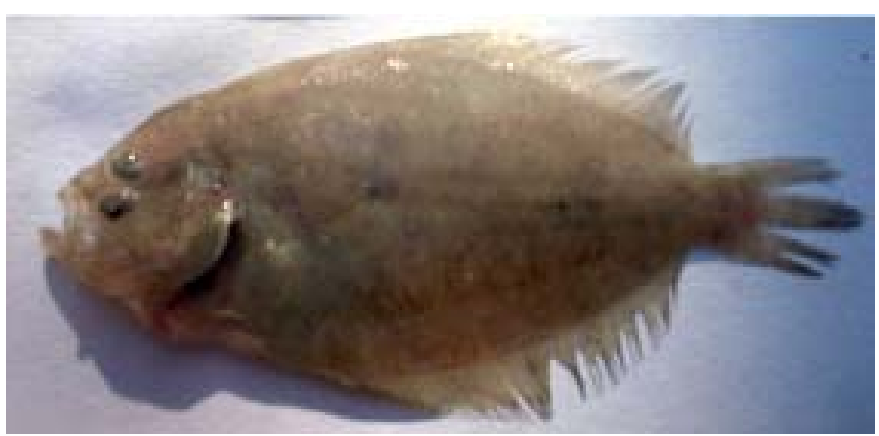

Image 41. Tongue Sole or Flounder Pseudorhombus arsius

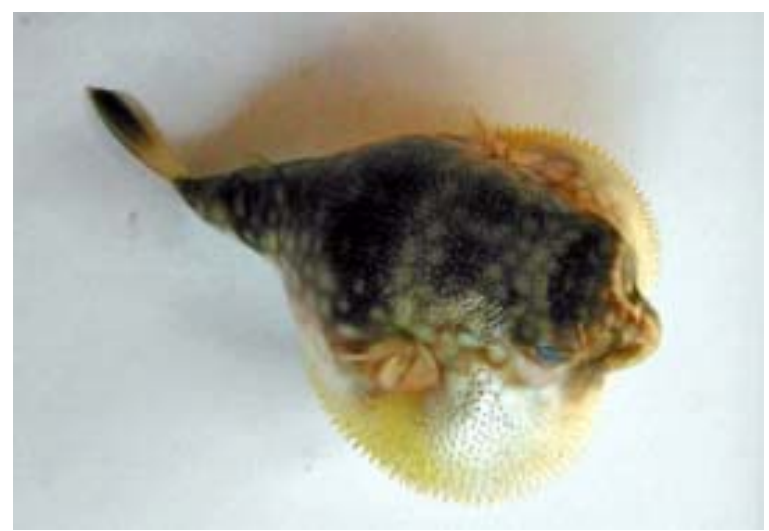

Image 42. Puffer Tetrodon fluviatilis

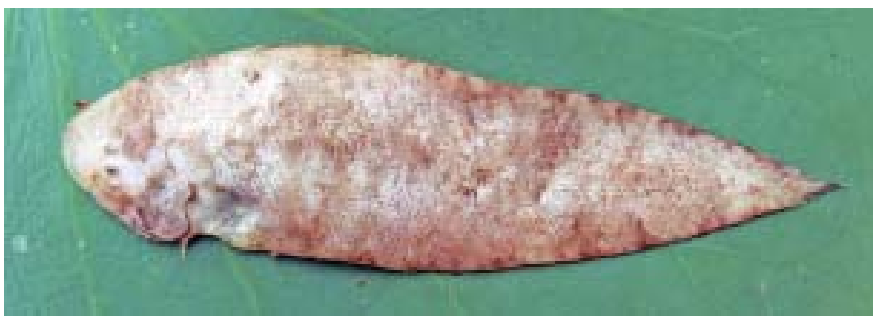

Image 43.Tongue Sole Cynoglossus sp.

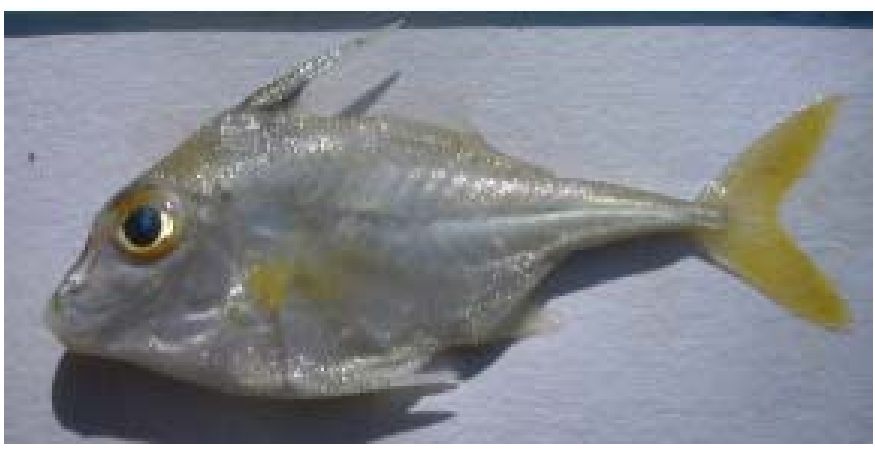

Image 44. Tripod Fish Triacanthus brevirostris 


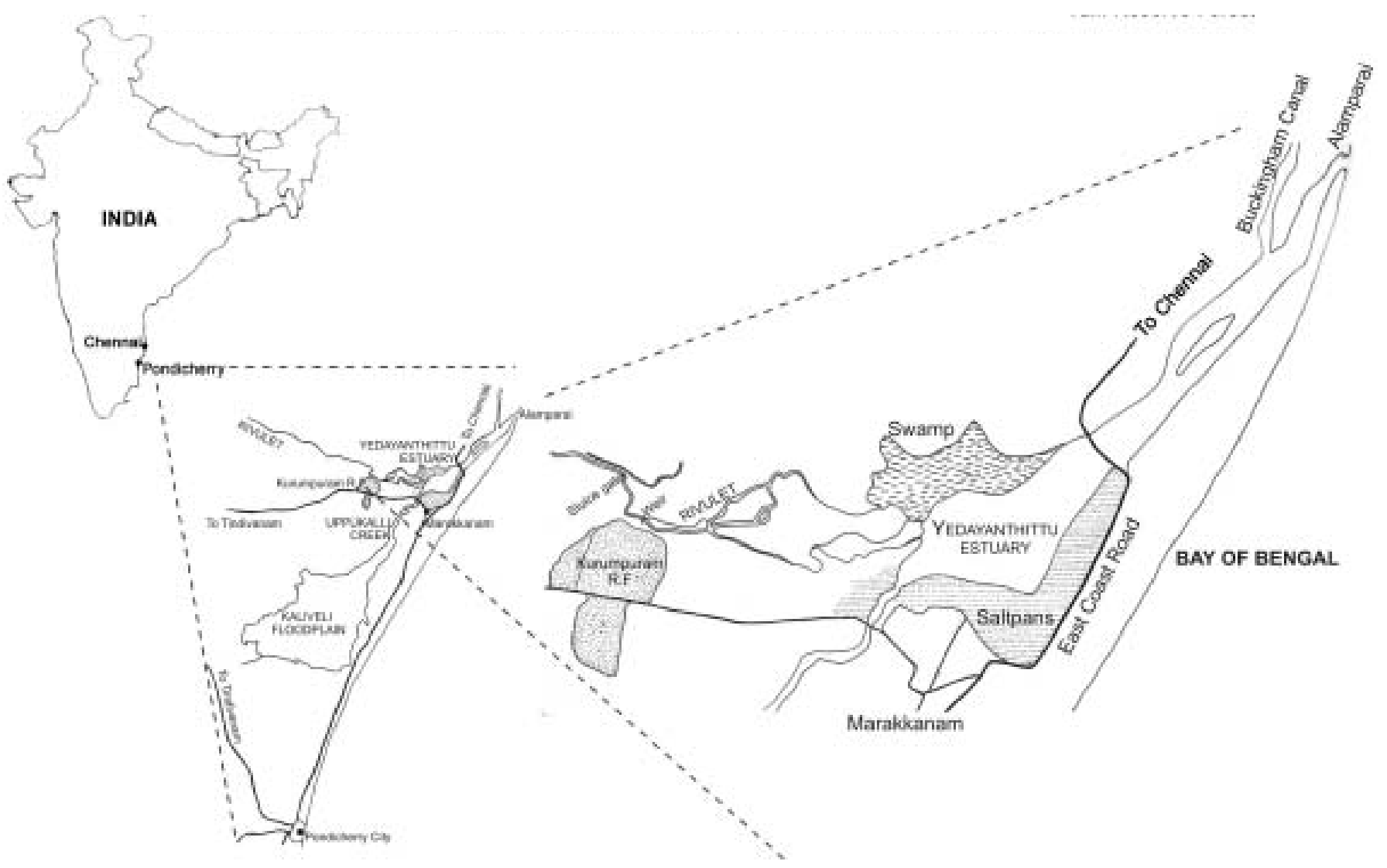

Figure 1. Areas of sampling - Yedayanthittu Estuary, Swamp and Rivulet north of Kurumpurum Reserve Forest

of Kaliveli Floodplain and Uppukalli Creek, Pondicherry, India, with some notes on habitat, distribution, status and threats. Zoos' Print Journal 20: 1967-1971.

Rangaswamy, C.P. (1975). Maturity and spawning of Mugil cephalus of Lake Pulicat. Recent Researches in Estuarine Biology. Ed. R. Natarajan. Hindustan Publishing Co., Delhi, 47-60.

Saxena, B.S. (1988). Culture of Tilapia in India - a policy issue. Proceedings of the First Indian Fisheries Forum. Asian Fisheries Society, Indian Branch, Mangalore, 39-40.

Talwar, P.K. \& A.G. Jhingran (1991). Inland Fishes of India and Adjacent
Countries. Oxford \& I.B.H., New Delhi, 541pp.

Talwar, P.K. \& R.K. Kacker (1984). Commercial Sea Fishes of India. Zoological Survey of India, Calcutta, 997pp.

Venkateswarlu, T. \& K.V. Rao (1986). Valid scientific names to Day's Fish Fauna of India. Records of the Zoological Survey of India. Occasional Paper 87: 48. 